\title{
Heuristic evaluation of e-dictionaries
}

Liezl H. Ball, (Department of Information Science, University of Pretoria, Pretoria, South Africa)

Theo J.D. Bothma, (Department of Information Science, University of Pretoria, Pretoria, South Africa)

Purpose - The purpose of this paper is to discuss the heuristic evaluations of five edictionaries according to the criteria developed by Ball and Bothma (2018). E-dictionaries are increasingly making use of modern information technology to create advanced information tools. It is necessary to ensure that these new products are still usable. Heuristic evaluation is a usability evaluation method used to evaluate the usability of a product.

Design/methodology/approach - Five e-dictionaries were evaluated through heuristic evaluation. This method requires an evaluator to evaluate a product by using a set of criteria or guidelines.

Findings - Various usability issues, as well as good features of e-dictionaries, could be identified through these evaluations, and are discussed under the categories of content, information architecture, navigation, access (searching and browsing), help, customisation and use of other innovative technologies.

Originality/value - Through the evaluations in this study, the criteria could be validated and an example of how the criteria can be used to evaluate e-dictionaries could be presented.

Keywords - e-dictionaries, electronic dictionaries, evaluation criteria, usability evaluation, heuristic evaluation, expert evaluation

Paper type - Research paper 


\section{Introduction}

Advances in technology continue to impact how we seek, find, and consume information. Many information sources have been affected by technology, including dictionaries. Tarp (2011) explains that technology has been applied to dictionaries in varying degrees. At the most basic level, content from dictionaries is scanned and serves as a digital copy of a physical text. The scans are images and no real search features are available. At the next level, technology is used to a greater extent, for example, the content might be in a database and retrieved via searching, but technology is not used in any innovative ways, basically providing print-based dictionaries that are now made available digitally. However, the digital medium brings such new and different possibilities to dictionaries, it is suggested that e-dictionaries be taken to a higher level and "designed from scratch with computer capabilities and computer search mechanisms in mind" (Nesi, 2000: 140).

There are many technologies that can be employed to enhance e-dictionaries: better search options (e.g. De Schryver, 2003; Lew, 2012; Verlinde \& Peeters, 2012); more data in the form of example sentences (De Schryver, 2003), multimedia (Lew, 2012) or linking to data external to the dictionary (Heid, Prinsloo \& Bothma, 2012); other innovative technologies such as filtering, annotations or recommendations (Bothma, 2011). Technology might also be used to create e-dictionaries customised according to the needs of users (e.g. Bothma, 2011; De Schryver, 2003; Gouws, 2014; Tarp, 2011). This could be customisation for specific situations or for the needs and characteristics of individuals (Tarp, 2009: 292). The function theory of lexicography formalises this idea that a dictionary should be customised according to different information need situations in which a user might find him-/herself. For a short discussion of the function theory, see Bothma and Tarp (2012). One example of this theory must suffice here: if a person is writing a text, (s)he will need different information to a person who is doing an in-depth study of the origin of a word or phrase. As such, the function theory suggests that an e-dictionary should be designed in such a way (using modern technology) that only the relevant information for a specific situation should be given. The other irrelevant information should be withheld so that the user is not overwhelmed.

If dictionaries are designed to make full use of the strengths inherent in the digital medium and break away from the traditions that have been established in their paper counterparts, very different information tools to what users are used to could be designed. If this is the case, it will be important to determine if these products are usable and acceptable to users or, in other words, the usability of edictionaries should be evaluated. Tullis and Albert (2008: 7) confirm that the more complex a product becomes, the more important it is to make sure that the usability is good (Tullis \& Albert, 2008: 7). The concept of usability has become increasingly important in software design (Preece, Rogers \& Sharp, 2011: 2). Informally it is accepted that usability indicates that something can be used for its intended purpose (Rubin, Chisnell \& Spool, 2008: 4). Usability is formally expressed in the ISO standard as "the extent to which a product can be used by specified users to achieve specified goals with effectiveness, efficiency, and satisfaction in a specified context of use" (ISO 9241-11, 1998), where effectiveness indicates whether the product can be used for its intended purpose and how well it accomplishes that particular purpose (Preece, Rogers \& Sharp, 2011: 19), efficiency refers to the ease with which a person can do that task or the effort that has to be exerted in reaching the intended goal (Heid, 2011: 291; Tullis \& Albert, 2008: 8) and satisfaction refers to a person's impression of or attitude towards the product (Heid, 2011: 292; Preece, Rogers \& Sharp, 2011: 13).

As the usability of a product has become so important, it is important that the usability of a product or system be determined through an evaluation. Evaluation is the activity where information about how users use a product is gathered and a judgement can be made as to whether it is actually usable and acceptable to users (Preece, Rogers \& Sharp, 2011: 433). There are various methods according to which a product can be evaluated. Fernandez, Insfran and Abrahão (2011: 790) explain that a usability evaluation method is "a procedure which is composed of a set of well-defined activities for collecting usage data related to end-user interaction with a software product and/or how the specific properties of this software product contribute to achieving a certain degree of usability." Examples of such 
methods are usability testing, inspection methods, inquiry methods, analytical modelling or simulations.

\section{Methodology}

The usability of five e-dictionaries was evaluated through heuristic evaluation. Heuristic evaluation is a type of inspection method that relies on experts to evaluate a product according to a set of criteria (Shneiderman \& Plaisant, 2010: 134-136). The criteria are used so that the evaluation is done systematically and specific usability problems can be identified. Criteria for the evaluation of webpages is available, but criteria specifically for the evaluation of e-dictionaries has been developed by Ball (2016) and Ball and Bothma (2018). Preece, Rogers and Sharp (2011: 507) confirm that general heuristics might not be specific enough for the evaluation of certain products and evaluators can adjust the heuristics or create their own. The expert (evaluator) typically goes through the system once to get accustomed to the system and then does a detailed evaluation using the specific heuristics (Barnum, 2010: 63; Nielsen, 1993: 158-159).

In this, study one expert reviewer did an in-depth evaluation according to the criteria specifically designed for the evaluation of e-dictionaries by Ball (2016) and Ball and Bothma (2018). An understanding of heuristic evaluation and how concepts such as information architecture, advanced searching and navigation are considered during an evaluation would also enable publishers or librarians to make informed decisions when evaluating e-dictionaries. The finer details of each criterion are made clear through the evaluations on the five e-dictionaries. For the sake of completeness, a summary of these criteria is included as an appendix.

The following five e-dictionaries were evaluated.

\subsection{Algemeen Nederlands Woordenboek (ANW) (General Dutch Dictionary) (2016)}

The ANW (Algemeen Nederlands Woordenboek) is a general Dutch dictionary for contemporary Dutch in the Netherlands and Flanders. It is an online, corpus-based, scholarly dictionary, covering words from 1970 onwards (Tempelaars, 2014: 2; Tiberius, Niestadt \& Schoonheim, 2014: 72). This project of the Institute of Dutch Lexicology in the Netherlands was designed as an e-dictionary from the beginning, to embrace the possibilities, as well as address the challenges, that the technological medium brings (ANW, 2015).

\subsection{Interactive Language Toolbox (ILT) (2016)}

The ILT (Interactive Language Toolbox) is the result of a research project of the Leuven Language Institute at the Katholieke Universiteit Leuven. It has been developed as a tool that can be used to help users with language related questions or problems and has been extended to include French, Dutch and English. It is a continuing project and various designs and options have already been implemented.

\subsection{Ordbogen over faste vendinger (Danish Dictionary of Fixed Expressions) (2016)}

The Danish Dictionary of Fixed Expressions is developed and maintained by the Centre for Lexicography, a research centre at the University of Aarhus. It is accessible from the website Ordbogen.com. The Danish Dictionary of Fixed Expressions is designed based on the function theory of lexicography and is divided into four dictionaries. There is one database and only a selection of the data in the database is presented to the user in each dictionary (Bergenholtz, 2012).

\subsection{Oxford English Dictionary (OED) (2016)}

The OED (Oxford English Dictionary) is a historical dictionary published by Oxford University Press. The purpose of this dictionary is to provide a record of the English language and therefore focuses on the history and development of words (OED, 2013a). Readers who wish to understand current usage of a word are advised to use other Oxford Dictionaries (OED, 2013b). It includes about 600000 words from over 1000 years (OED, 2013a) and shows how the language has changed over time (OED, 2013b). The first $O E D$ was published in 1884, a version was released on CD-ROM in 1992, 
and in 2000 the dictionary was made available online (OED, 2013c). The online $O E D$ was evaluated in this study.

\subsection{Afrikaanse idiome-woordeboek (Afrikaans Dictionary of Fixed Expressions) (2016)}

The Afrikaanse idiome-woordeboek is a prototype e-dictionary of Afrikaans fixed expressions which only contains a subset of the expressions in the Afrikaans language. The purpose of the dictionary was to test certain theories and the functionality that can be included in an e-dictionary. As such, visual design and other aesthetic issues were not considered. The design of this dictionary is based on the function theory of lexicography and offers several dictionaries that are created from one large database (Bergenholtz, Bothma \& Gouws, 2011: 36). The e-dictionary also makes use of various advanced technologies, such as multimedia, filtering, advanced search and display, browsing and customisation. Usability testing (task-based evaluations) was done on this e-dictionary and is reported on in Ball (2016) and Ball and Bothma (2017a \& b). In these evaluations several users were observed while doing various tasks based on the criteria for e-dictionaries.

\section{Findings}

The findings will be discussed under the broad categories of the evaluation criteria.

\subsection{Content}

The key points that are considered under content are the level of complexity (including the use of external sources to provide more information), currency, credibility, writing style and use of multimedia.

The level of complexity of the information presented to a user cannot be adjusted in any of the edictionaries that were evaluated. The level of detail or the amount of information given can be adjusted to varying degrees. The Danish Dictionary of Fixed Expressions and Afrikaanse idiomewoordeboek allow a user to change the amount of data given in an article by selecting different functions. Each function displays different fields. This will be explained in more detail in the next section (information architecture). The ILT presents various options to a user that allow a person to select only the information that (s)he is interested in, for example, to see only the data for the pronunciation of an item. This will also be explained in more detail in the next section. The $O E D$ allows a user to show/hide specific elements for an entire article, whereas the $A N W$ allows a user to show/hide items for individual senses or meanings.

External sources referenced from an e-dictionary are useful in providing more information in an edictionary. Of the e-dictionaries that were evaluated, the ILT made the most use of external sources. In some cases the data from external sources were extracted from the original and used in the dictionary, and at other times only the link to the external source was given for more information. For example, Figure 1 shows links to external sources for translations of a word and Figure 2 shows data that have been extracted from an external source and displayed in the e-dictionary. 


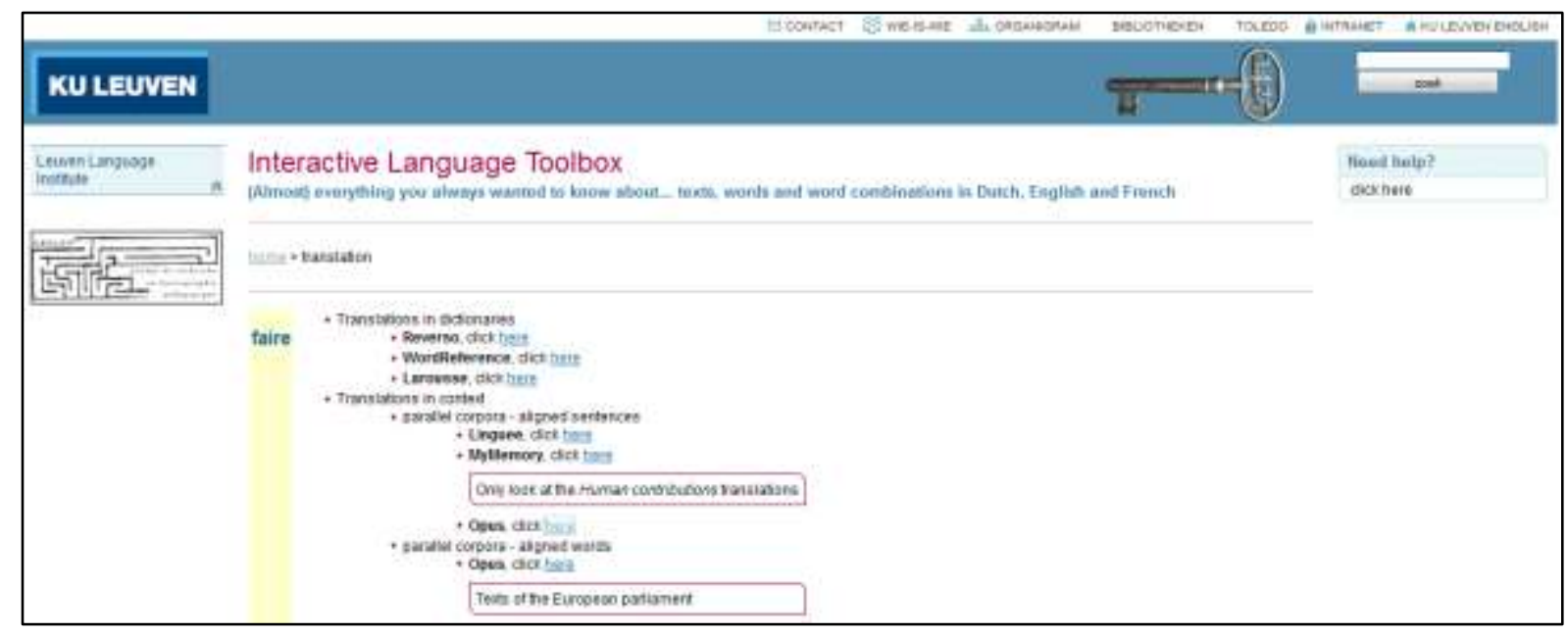

Figure 1 Links to external sources on the translations page in the ILT

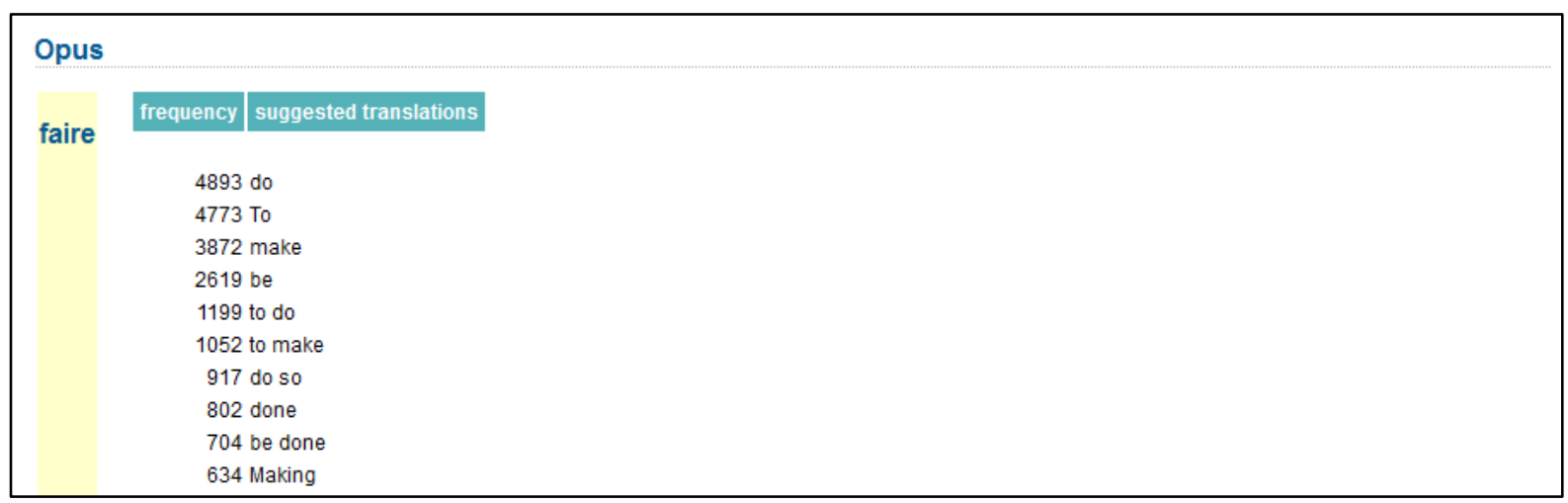

Figure 2 Data from the corpus 'Opus' pulled through and displayed on the translations page in the ILT

The $A N W$ provides links to external sources on the article/lemma level. This e-dictionary also uses external sources for multimedia. Figure 3 shows links to external sites using the lemma as search term in these sites. The user will have to distinguish between different senses on these sites. The figure also shows a link to an external site for the audio of the first sense. The $A N W$ and $O E D$ allow a user to search for examples from a specific author, sources and a certain time period. The Afrikaanse idiomewoordeboek allows a user to search for examples by a certain author. In each case the user does not search in the sources directly, but in the examples that have been added to the e-dictionary already. The Danish Dictionary of Fixed Expressions does not reference the sources from where examples are taken and there are only a few links to external sources, such as Wikipedia, for more information. 


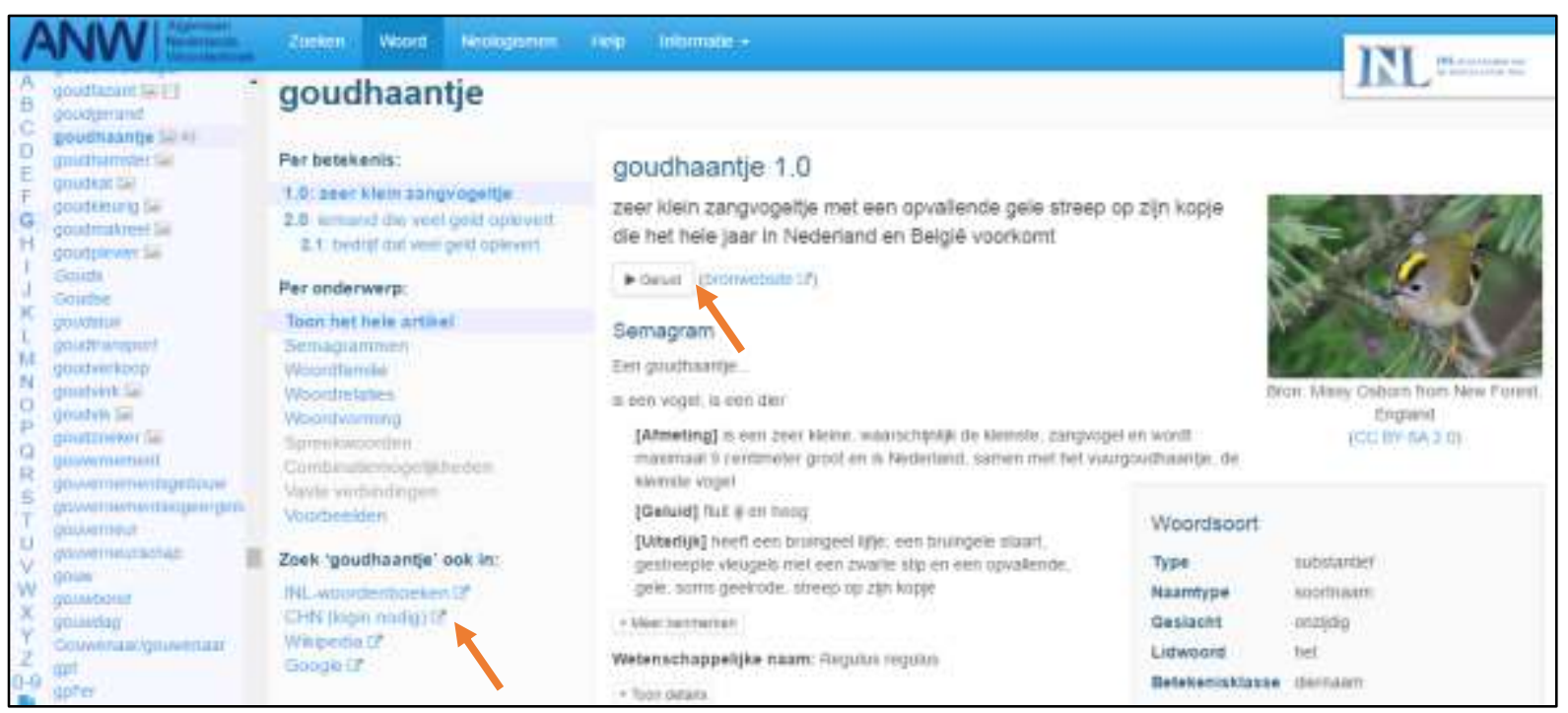

Figure 3 Links to external sites in the $A N W$

The way in which the currency is indicated differs among the e-dictionaries. The $O E D$ is the most meticulous in this regard and carefully records the history of each article. The ANW and ILT only state when the dictionary as a whole was last updated. The Danish Dictionary of Fixed Expressions and Afrikaanse idiome-woordeboek only give a copyright notice.

In all the e-dictionaries that were evaluated it is easy to establish the entity that is responsible for the e-dictionary, which gives credibility to the e-dictionary. All the dictionaries, except the ILT, also provide contact details for the editors. The Danish Dictionary of Fixed Expressions has the most options through which users can contact or communicate with the editors. Figure 4 shows comments from a user on an article in the Danish Dictionary of Fixed Expressions.

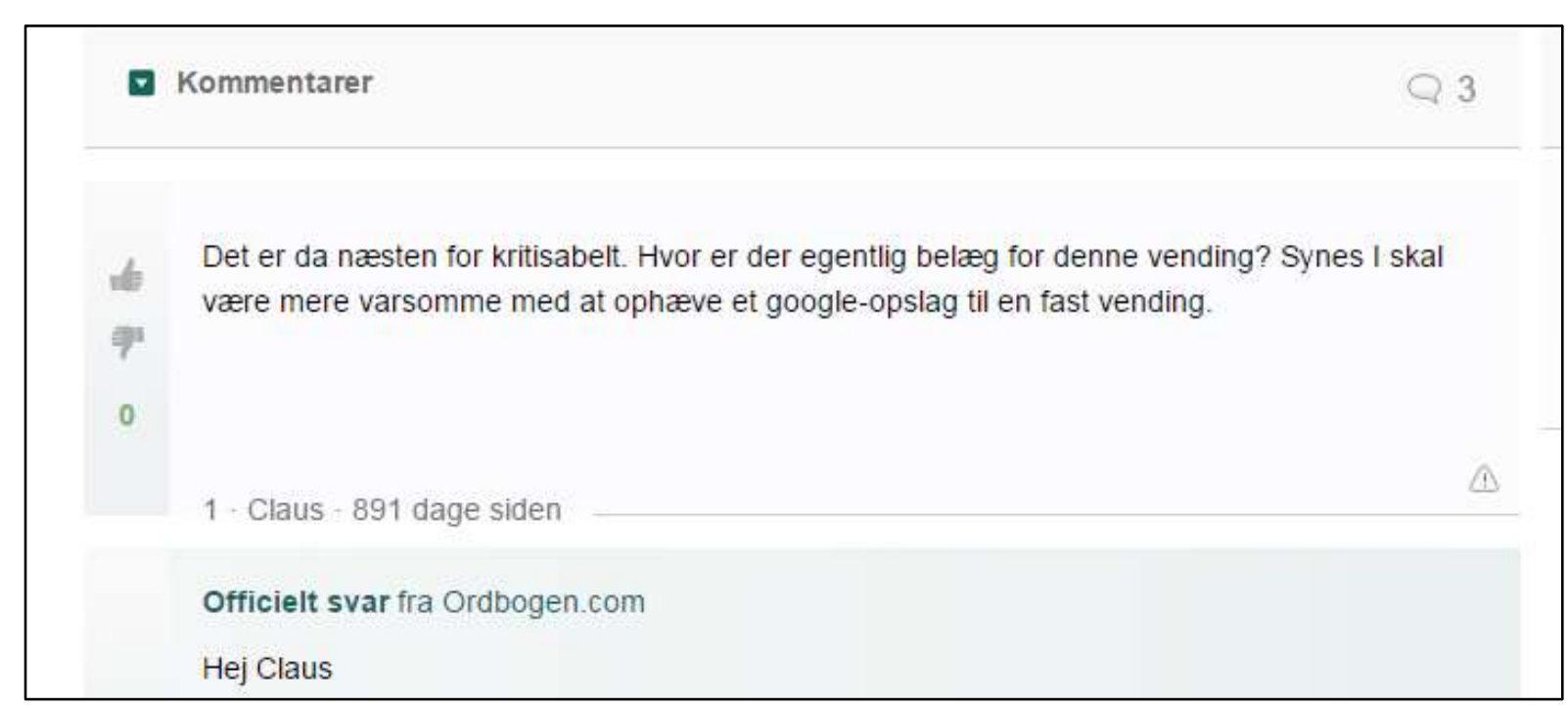

Figure 4 Comments on an article in the Danish Dictionary of Fixed Expressions

Very few abbreviations or symbols were noted in the ANW, ILT, and the Danish Dictionary of Fixed Expressions. The $O E D$ uses abbreviations and symbols widely and the Afrikaanse idiomewoordeboek uses them when referring to sources. Most labels, headings and page titles in the edictionaries were clear and easy to understand.

It is disappointing that not more multimedia is used. Only the $I L T$ and $O E D$ include links to sound files for pronunciation. The $A N W$ and the Afrikaanse idiome-woordeboek include images. The $A N W$ 
also has audio and video files. The sound files in the $A N W$ are not for pronunciation but to illustrate a concept, for example, the sound of a certain bird. Both the ANW and Afrikaanse idiome-woordeboek obtain multimedia from external sources. For example, Figure 5 shows the word 'a capella' illustrated with a video from YouTube.

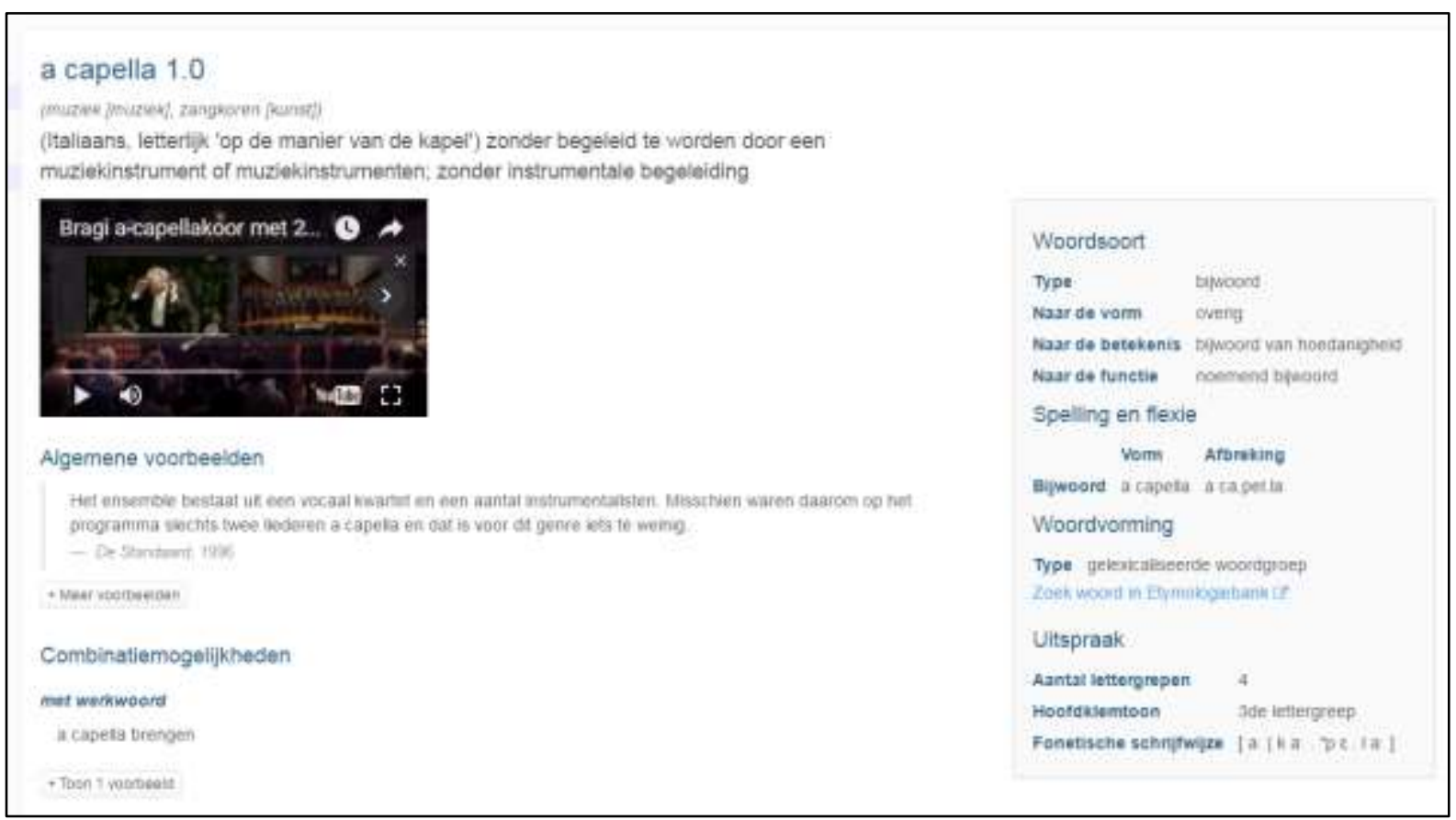

Figure 5 A video embedded in the $A N W$

\subsection{Information architecture}

The information architecture of a site refers to the way in which the information is organised or structured. In the case of e-dictionaries, a user will most often simply search for an item and get access to the specific item. However, there is often an underlying structure that can be presented to the user or that could affect the use of the e-dictionary and as such should be evaluated. Under this category, the layout of the page is also evaluated, particularly if the data on the page are ordered logically, if it is easy to scan the page and if a user can specify what information should appear on a page.

The ANW, OED and Afrikaanse idiome-woordeboek offer a type of macrostructure to the user in the form of an alphabetical list of the lemmas they contain. This means the user can browse through the content of the e-dictionary without having a specific need. See, for example, the structure presented in the $A N W$ in Figure 6. 


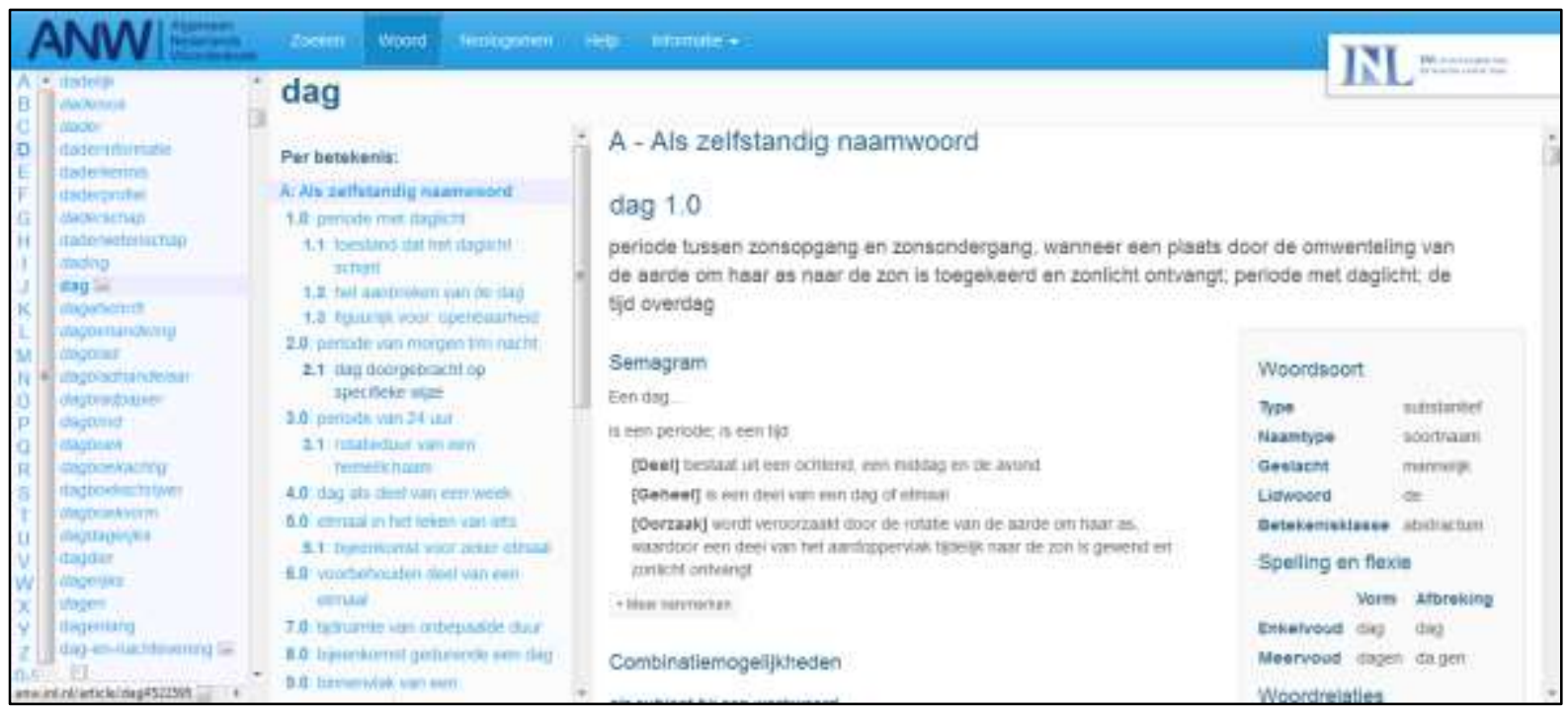

Figure 6 Structure presented in the $A N W$

The ILT and Danish Dictionary of Fixed Expressions do not display such a structure of the content to the user and the user has to search for what (s)he wants to find.

The ILT, Danish Dictionary of Fixed Expressions and the Afrikaanse idiome-woordeboek have organised the data in the dictionary in such a way that the user can get only relevant information for a specific situation. The ILT does this through the options from which a user can choose once a search term has been entered. Figure 7 shows that a word has been entered and different options to select from are displayed on the right, for example, to see translations, definitions or synonyms.

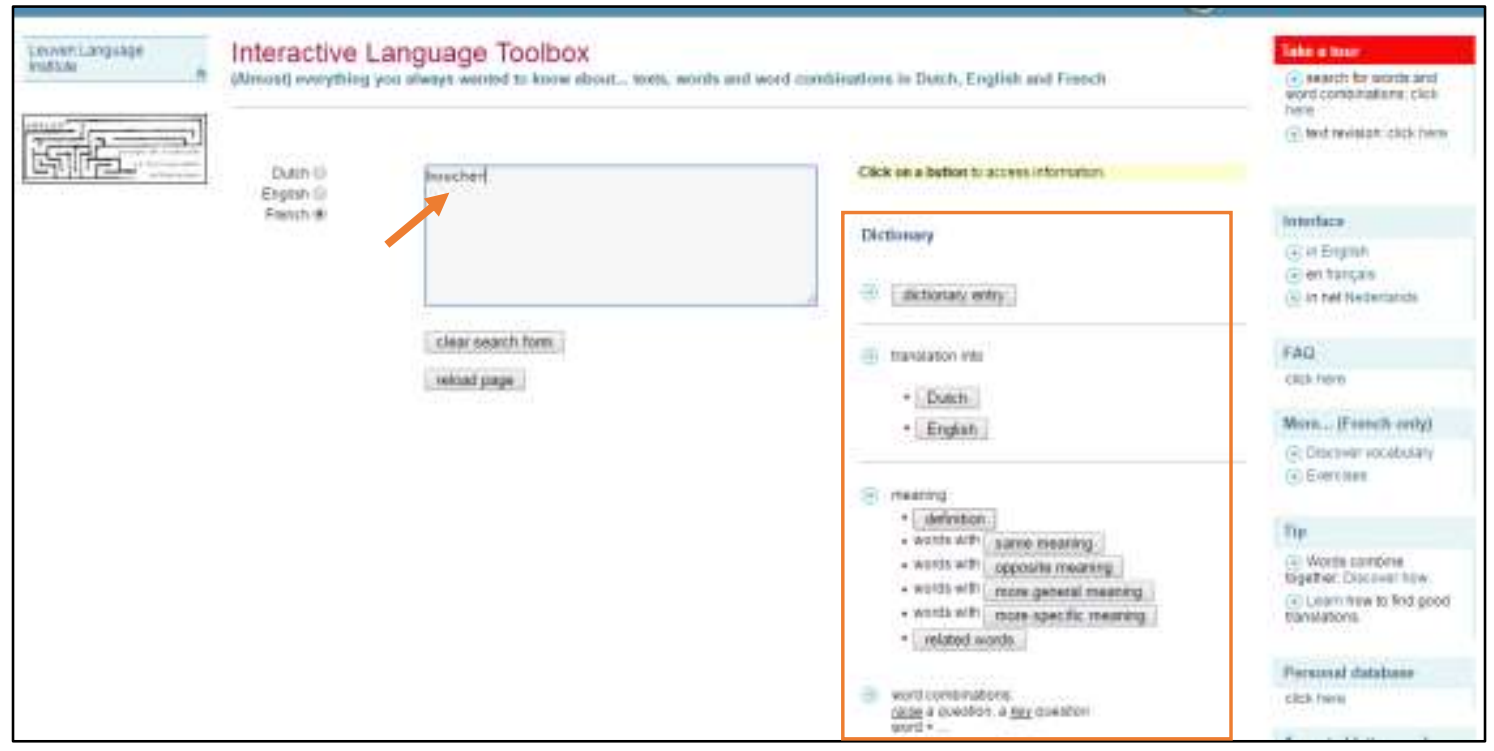

Figure $7 \mathrm{~A}$ word is entered into the search field and various options relevant to a query are listed on the right in the $I L T$

The Danish Dictionary of Fixed Expressions and the Afrikaanse idiome-woordeboek make use of different functions and each function presents a different selection of data to the user. For example, in the Afrikaanse idiome-woordeboek the function Ek wil basiese inligting oor die idioom hê ('I want to have basic information about an expression') only shows a few fields from the database, whereas the function $E k$ wil alles oor ' $n$ idioom weet ('I want to know everything about an expression') shows most fields. The functions in the Afrikaanse idiome-woordeboek are shown in Figure 8. 
Soek op enige woord(e) of term(e) in die idioom

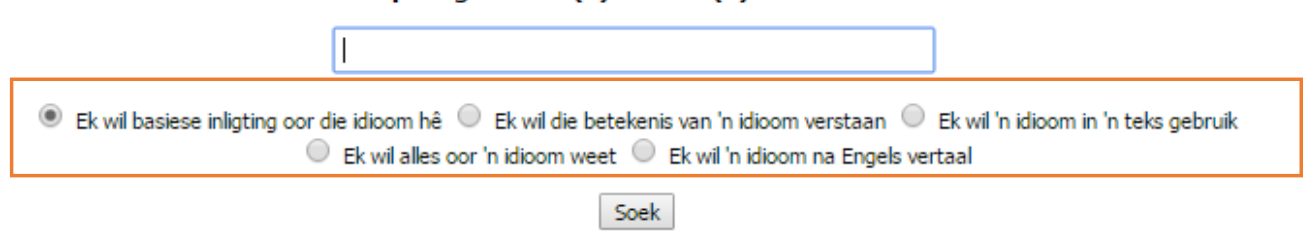

Figure 8 Functions in the Afrikaanse idiome-woordeboek

Figure 9 shows an expression with the function 'I want to know everything about an expression' selected.

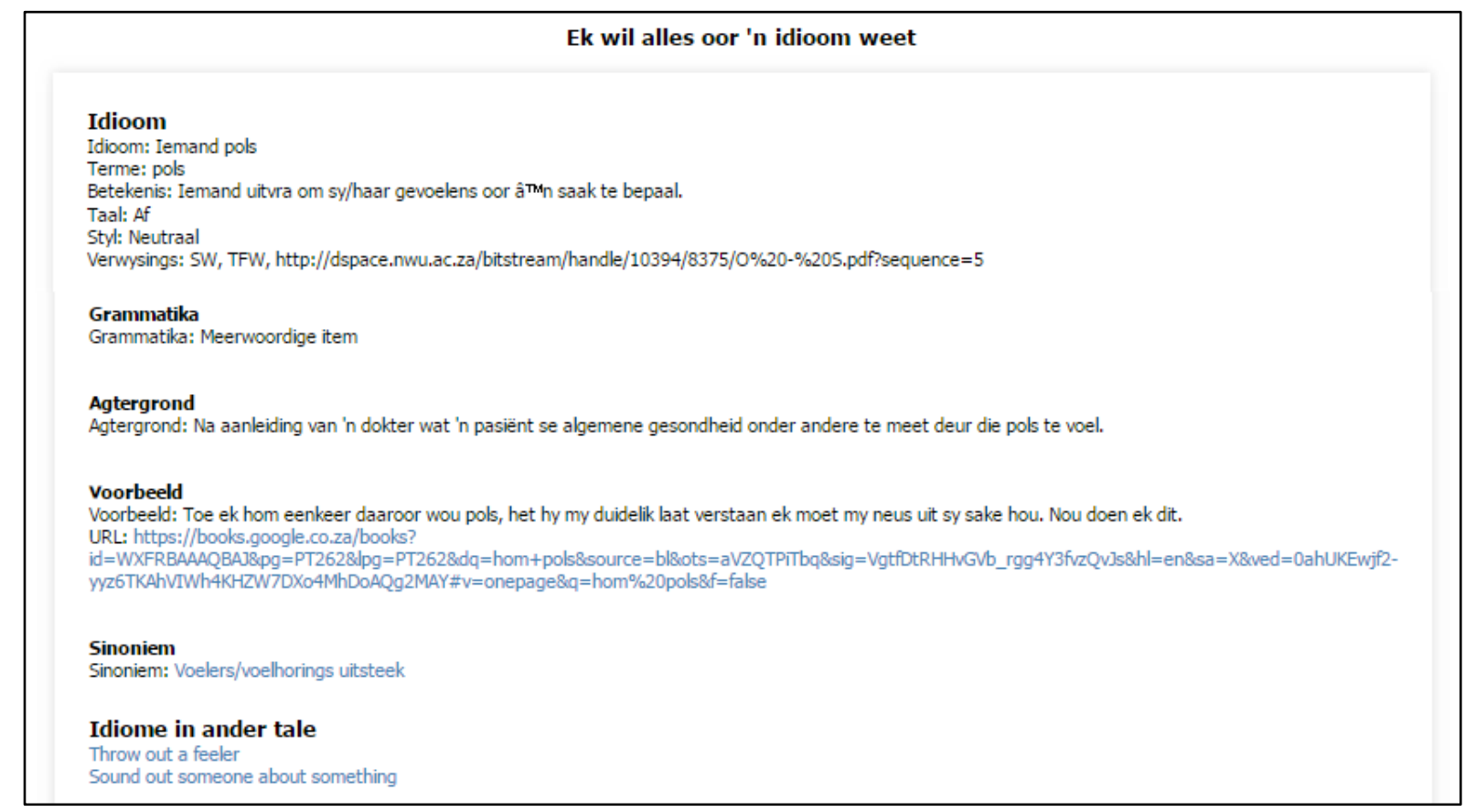

Figure 9 An expression with the function 'I want to know everything about an expression' selected in the Afrikaanse idiome-woordeboek.

The Danish Dictionary of Fixed Expressions offers four different functions to a user, presented as four different dictionaries, namely, forstå en vending 'understand an expression', skrive en tekst 'write a text', søge efter en vending ud fra en betydning 'search for an expression with a certain meaning' and vide mere om en vending 'find out more about an expression'. Each dictionary is accessible through a tab under the basic search field as can be seen in Figure 10. In this figure, an expression has been searched for and the data for that expression from the second dictionary (Use of Fixed Expressions or 'write a text') is shown. 


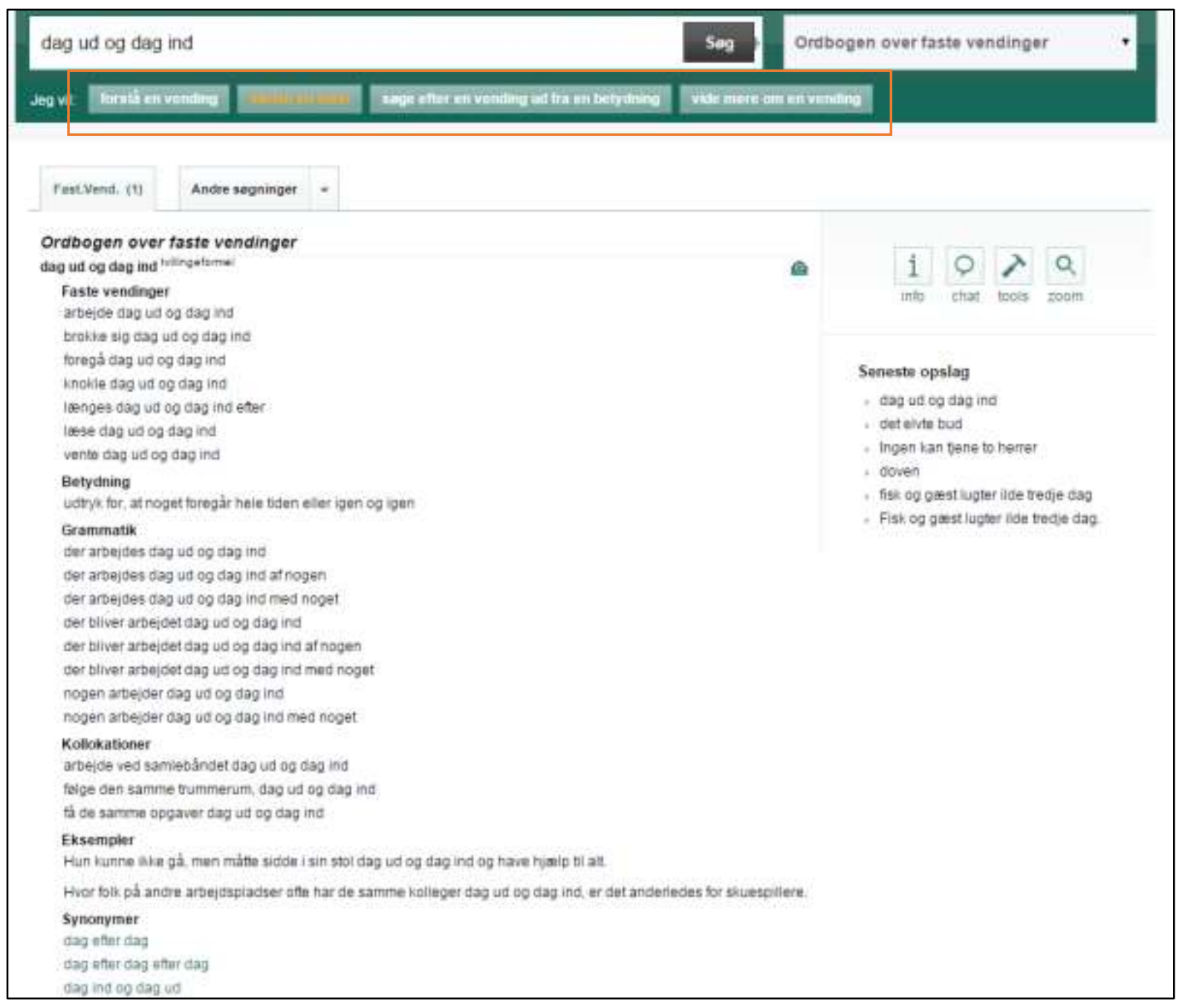

Figure 10 The four functions in the Danish Dictionary of Fixed Expressions with the second dictionary ('write a text') selected

The pages for articles in all the dictionaries, except the $I L T$, are clearly ordered and seem easy to scan to find appropriate information. The home page of the ILT is clearly organised, but the next level pages seem more difficult to process. Though the articles of the $O E D$ are well organised, the articles can be very long, which can prevent a user from accessing data quickly. As the purpose of the $O E D$ is to record the usage of the English language over time, the oldest usage of a word is given first, not necessarily the most common current usage, which can be confusing if a user is not familiar with the purpose of the $O E D$.

As has been explained in the discussion regarding content, both the $A N W$ and the $O E D$ allow the user to manipulate the data that are displayed on a page by showing or hiding some fields, the $O E D$ on a fairly general level and the $A N W$ on a fairly detailed level. The $I L T$ allows a user to be very specific about what information is to be displayed on a page, by allowing the user to select the information (s)he needs at the time of searching, for example, pronunciation information. The Danish Dictionary of Fixed Expressions and the Afrikaanse idiome-woordeboek both allow the user to specify which data should be shown on a page through the use of functions. The data in each function have been determined by lexicographers and cannot be changed by a user. However, in addition to functions, the Afrikaanse idiome-woordeboek has advanced search and display options where a user can specify exactly which fields to display on a page. In this way the user can create a custom article. In Figure 11 , the user has selected to see only the author and example sentences fields. 


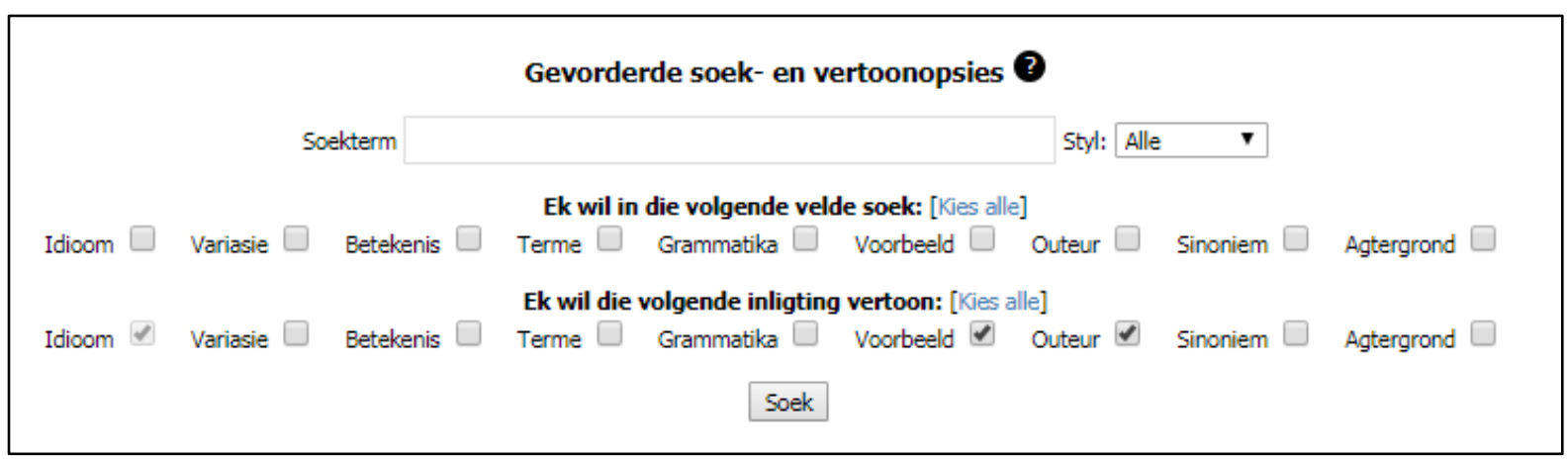

Figure 11 Specific fields can be selected to be displayed in the article in the Afrikaanse idiome-woordeboek

The ILT, Danish Dictionary of Fixed Expressions and the Afrikaanse idiome-woordeboek do not allow any further customisation once the article is displayed.

\subsection{Navigation}

Under the category of navigation one should evaluate how easy it is to navigate in the e-dictionary, particularly how quickly a user can get to the needed information, also whether the user can easily orientate him-/herself and if the links that enable a user to navigate in a system are clear and easy to understand.

The path to specific articles in all the dictionaries is reasonably short. In the ANW, Danish Dictionary of Fixed Expressions, OED and Afrikaanse idiome-woordeboek, a user types in a search statement. If there is more than one result, the results are listed and the user can choose the most relevant option from the list. Both the $A N W$ and the Afrikaanse idiome-woordeboek show a results list, even when there is only one result. The ILT does not have a results page, but if there is more than one sense, the links to relevant senses in the article are shown. The $A N W, I L T$ and $O E D$ have other navigation options in the articles themselves so that a user can navigate easily within an article. For example, in the $O E D$ each article has a panel to the right with a list of links to all the elements in the article (see Figure 12) and there is a profile for each article (see Figure 13). However, the article profile does not appear easy to interpret. 


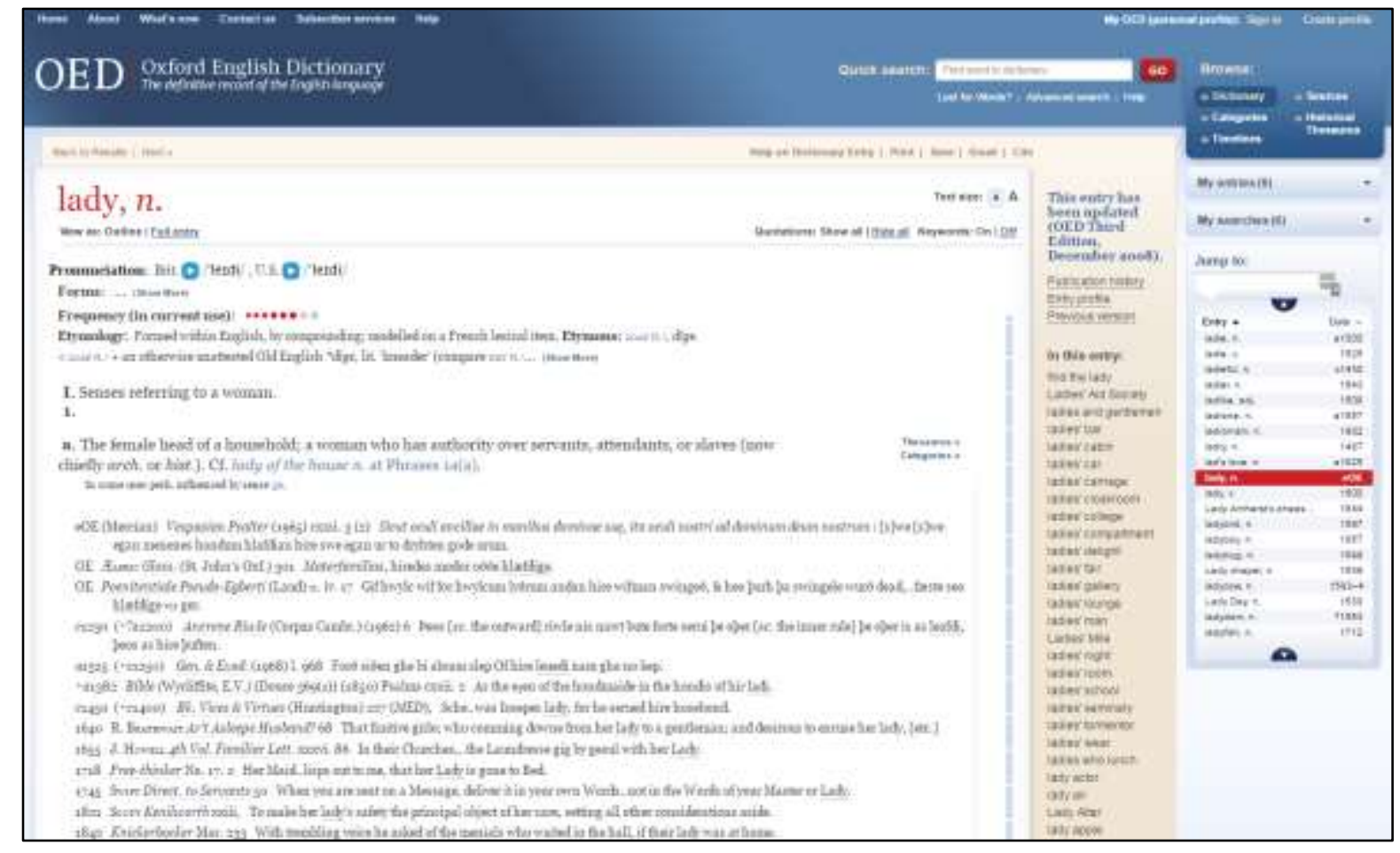

Figure 12 A list of links that allows browsing in an article in the $O E D$

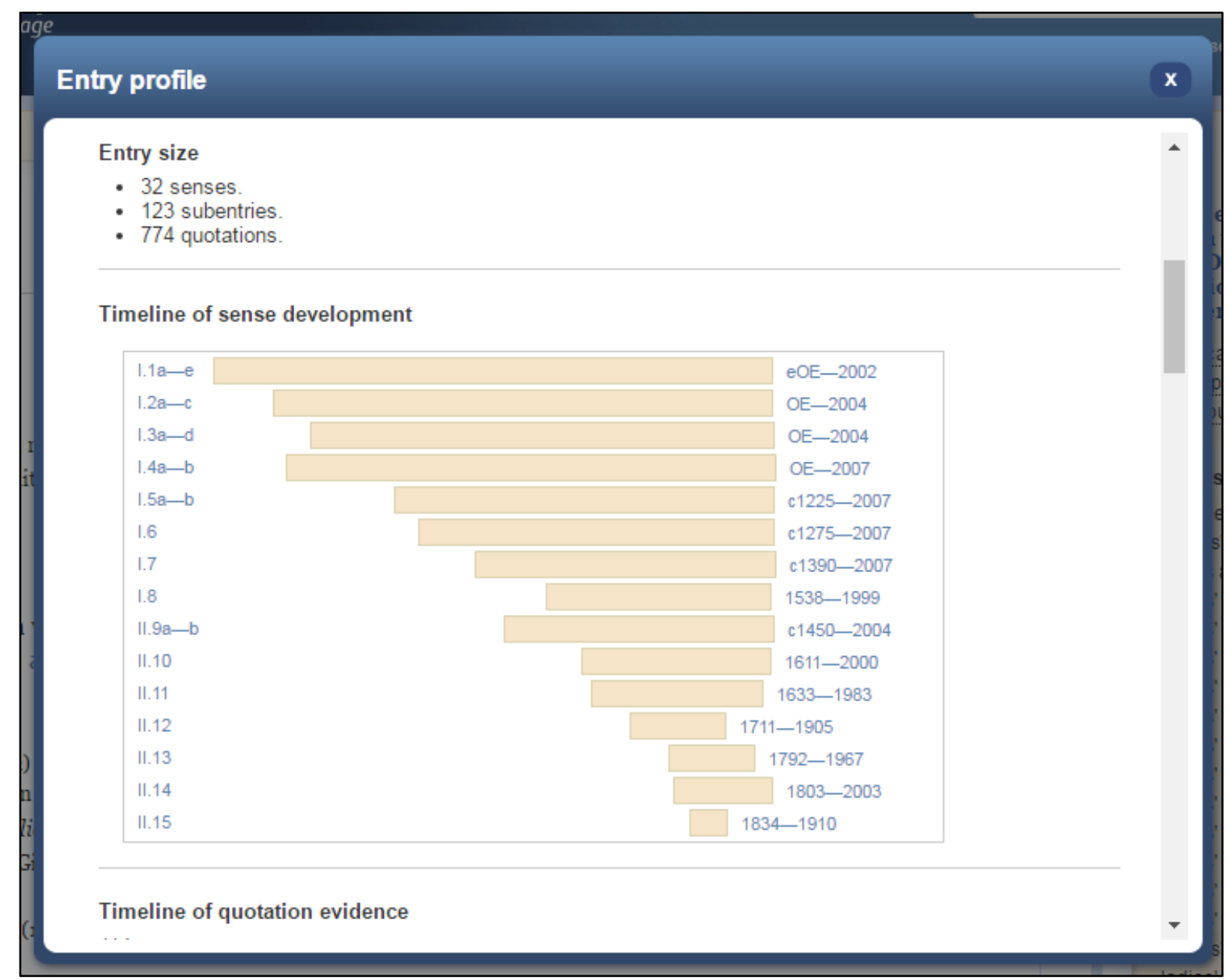

Figure 13 The profile of the article for 'lady' in the $O E D$ 
The user's position in the e-dictionary is clearly indicated in all the dictionaries. The $A N W$ and $O E D$ show the current article's position in terms of an alphabetical lemma list. The $A N W$ also has a menu in each article that highlights the user's position in the current article (see Figure 14).

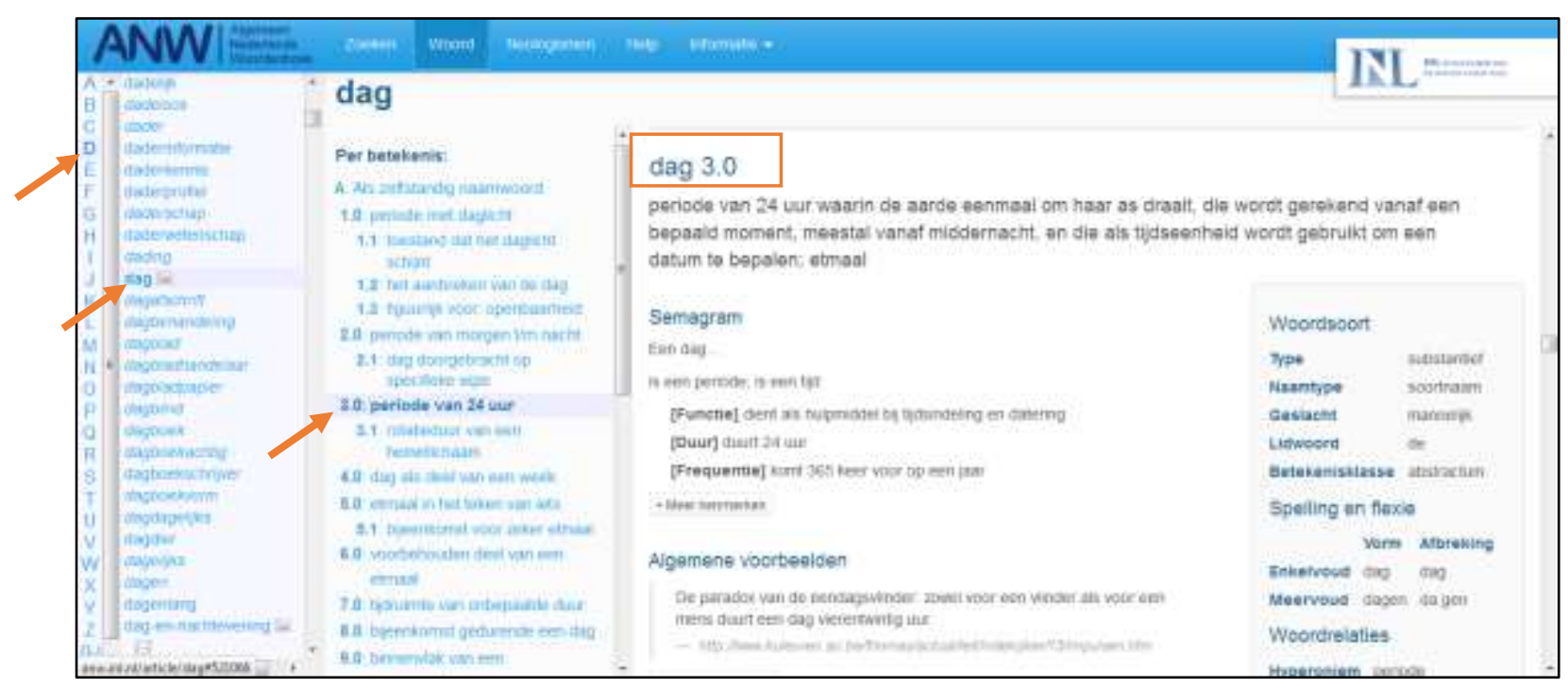

Figure 14 The user's position in the $A N W$ is clearly indicated

The ILT and Danish Dictionary of Fixed Expressions do not offer a lemma list, but rather show the user which option or function has been selected. The ILT makes effective use of breadcrumbs to highlight a user's position. The Danish Dictionary of Fixed Expressions changes the colour of the tab of the selected function. The Afrikaanse idiome-woordeboek shows the selected function through a heading. As it is a prototype, visual design was not considered and the colour of the selected function does not change and the link remains active. The Afrikaanse idiome-woordeboek also offers a browsing option that shows the lemma list.

Only the $A N W$ specifically indicates the difference between an internal and external link through the use of a symbol. The external links in the Danish Dictionary of Fixed Expressions and Afrikaanse idiome-woordeboek are written out (the full URL is shown) so a person might anticipate that it goes to a site in a different domain. The $O E D$ has so few external links that any remarks regarding the matter will be insignificant. The use of internal and external links in the ILT is very confusing (see Figure 15). The style of links is not consistent, sometimes links and sometimes buttons are used.

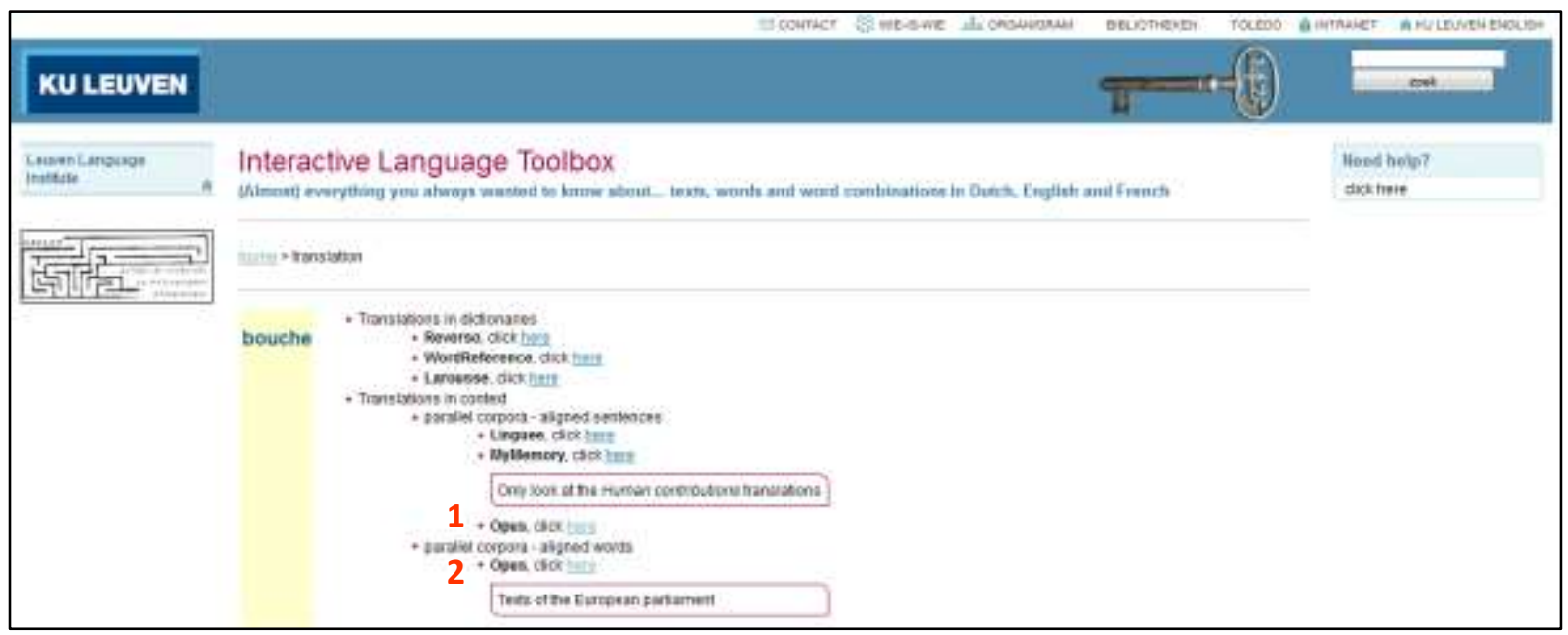

Figure 15 'Opus, click here' (1) leads to an external site (http://opus.lingfil.uu.se), whereas 'Opus, click here' (2) leads to a section lower down on the same page in the $I L T$ 
The links in all the e-dictionaries seem to be clearly labelled so that a user can be confident the link leads to the place that is suggested in the name of the label.

The last item to consider when evaluating links is whether there are links to other items in the edictionary. Only the ILT does not have some links to other articles in the dictionary from words in the current article. The $A N W$ uses links of this kind extensively, and includes links to other compound words in which the current sense (meaning) is used in.

\subsection{Search and browse}

When evaluating the type of access options an e-dictionary provides to the data it holds, the evaluator should consider the basic as well as advanced search options, browsing and filtering options, and the way in which the search results are displayed.

The basic search field is available, and clearly visible, on the home page of all the e-dictionaries that were evaluated. However, only the Danish Dictionary of Fixed Expressions and the OED have the basic search field on the subsequent pages as well. In the ANW, ILT and Afrikaanse idiomewoordeboek, the user has to navigate back to the home page to do a new search. Both the Danish Dictionary of Fixed Expressions and the Afrikaanse idiome-woordeboek save the user's search and a user can easily change from one function to the next. The ILT, however, does not save a search and a user could choose to see some aspect of the search term, such as pronunciation, but if (s)he would like to change to see some other information, the search has to be repeated.

The ILT has various symbols that can be used when searching, such as a tilde ( ) to search for synonyms. Wildcard characters can be used in the $A N W, I L T$ and $O E D$. The $O E D$ furthermore allows for Boolean operators and proximity operators to be used in an advanced search. All the e-dictionaries allow a user to search in certain fields to some degree. The OED and Afrikaanse idiome-woordeboek allow a user to specify directly which fields to search in (see Figure 16 and Figure 17).

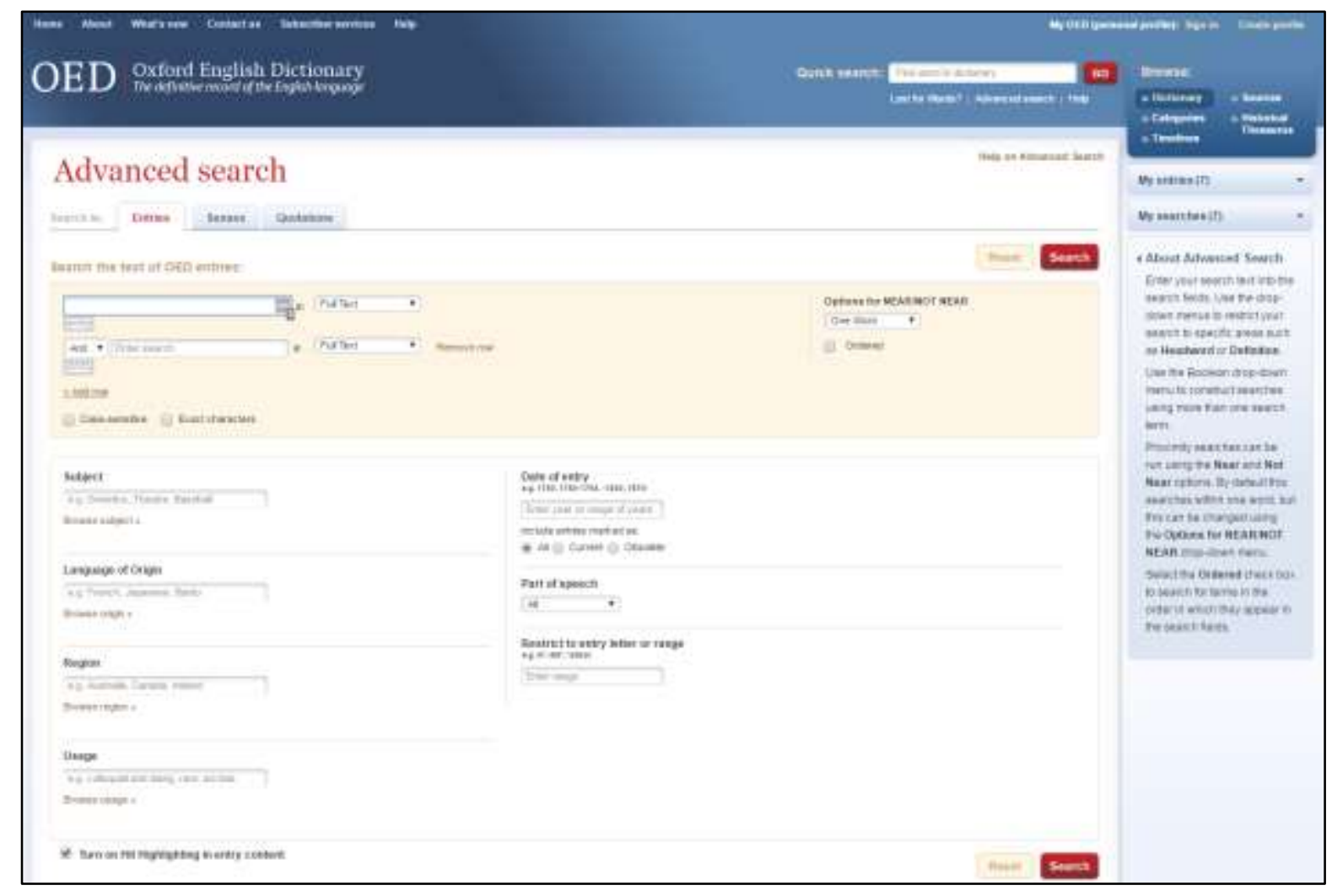

Figure 16 Advanced search in the $O E D$ 


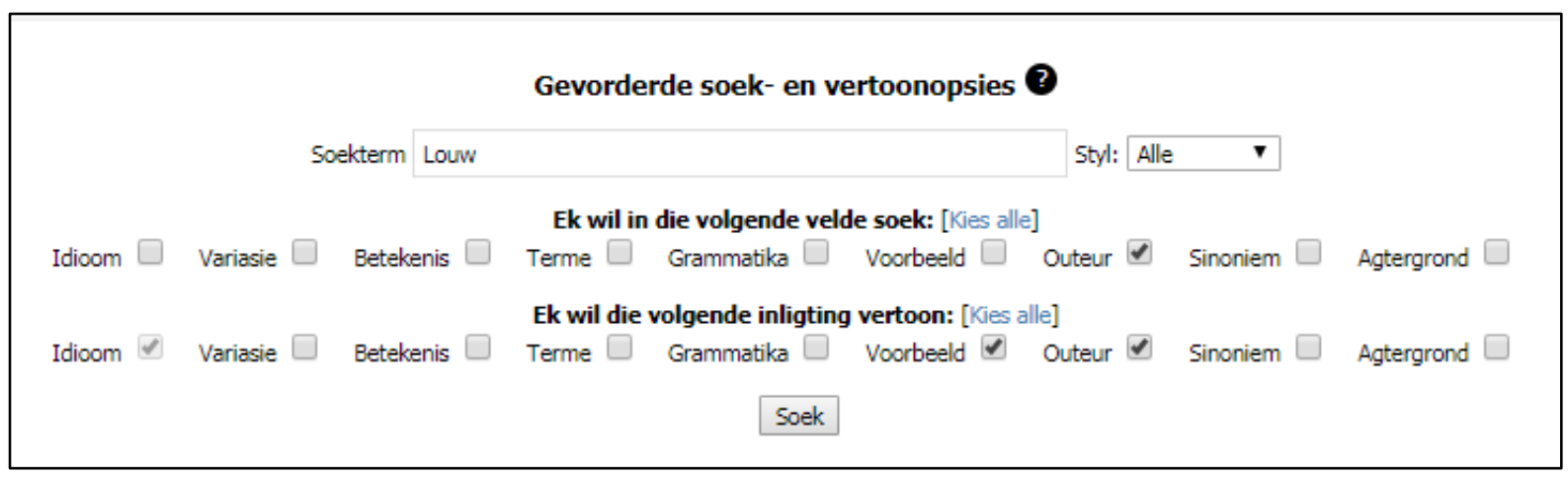

Figure 17 Advanced search in the Afrikaanse idiome-woordeboek to find example sentences by a specific author (and display the example sentences and author fields)

The $A N W$ allows the user to search through certain characteristics (see Figure 18), for example, a user can specify to search words with a certain number of syllables (aantal lettergrepen) or with the emphasis on a specific syllable (hoofdklemtoon op ... lettergreep).

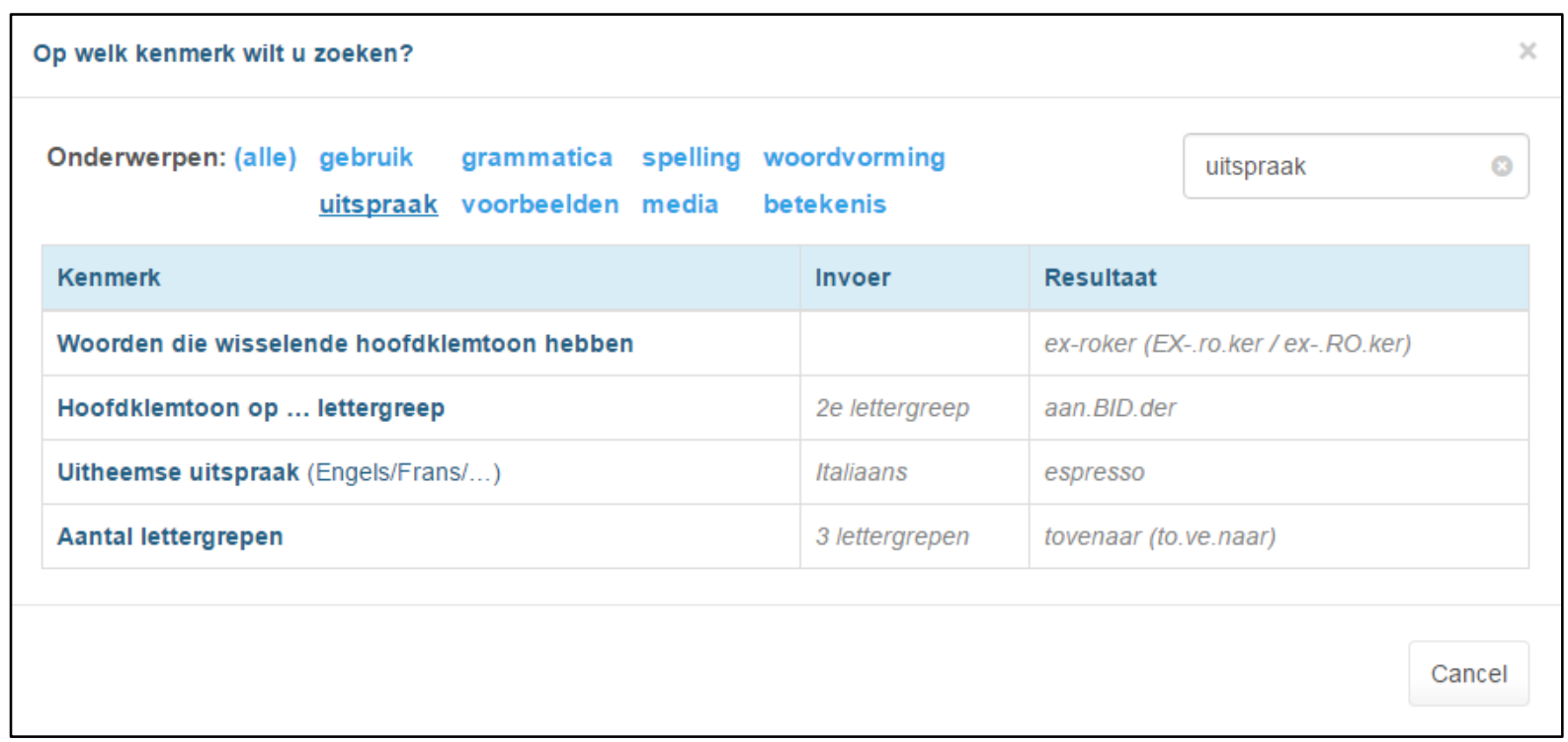

Figure 18 Searching according to characteristics in the $A N W$

The ILT and Danish Dictionary of Fixed Expressions do not offer the ability to search in specific fields directly. In the $I L T$, a user does in effect select a specific field to search in when selecting a certain option. In the Danish Dictionary of Fixed Expressions (and the Afrikaanse idiomewoordeboek), a user implicitly searches in specific fields when selecting different functions. However, these fields have been predetermined by the lexicographers and are not transparent to the user.

The ANW, OED and Afrikaanse idiome-woordeboek allow the user to browse through the items in the e-dictionary through some form of list. The $O E D$ also allows a user to browse through categories, timelines, sources or a historical thesaurus.

One way to give access to content in a database is to apply filters. The $A N W$ allows this to some extent by allowing the user to search according to a specific characteristic. The $O E D$ is the only edictionary that allows manipulation of the result set by applying filters (see Figure 19). 


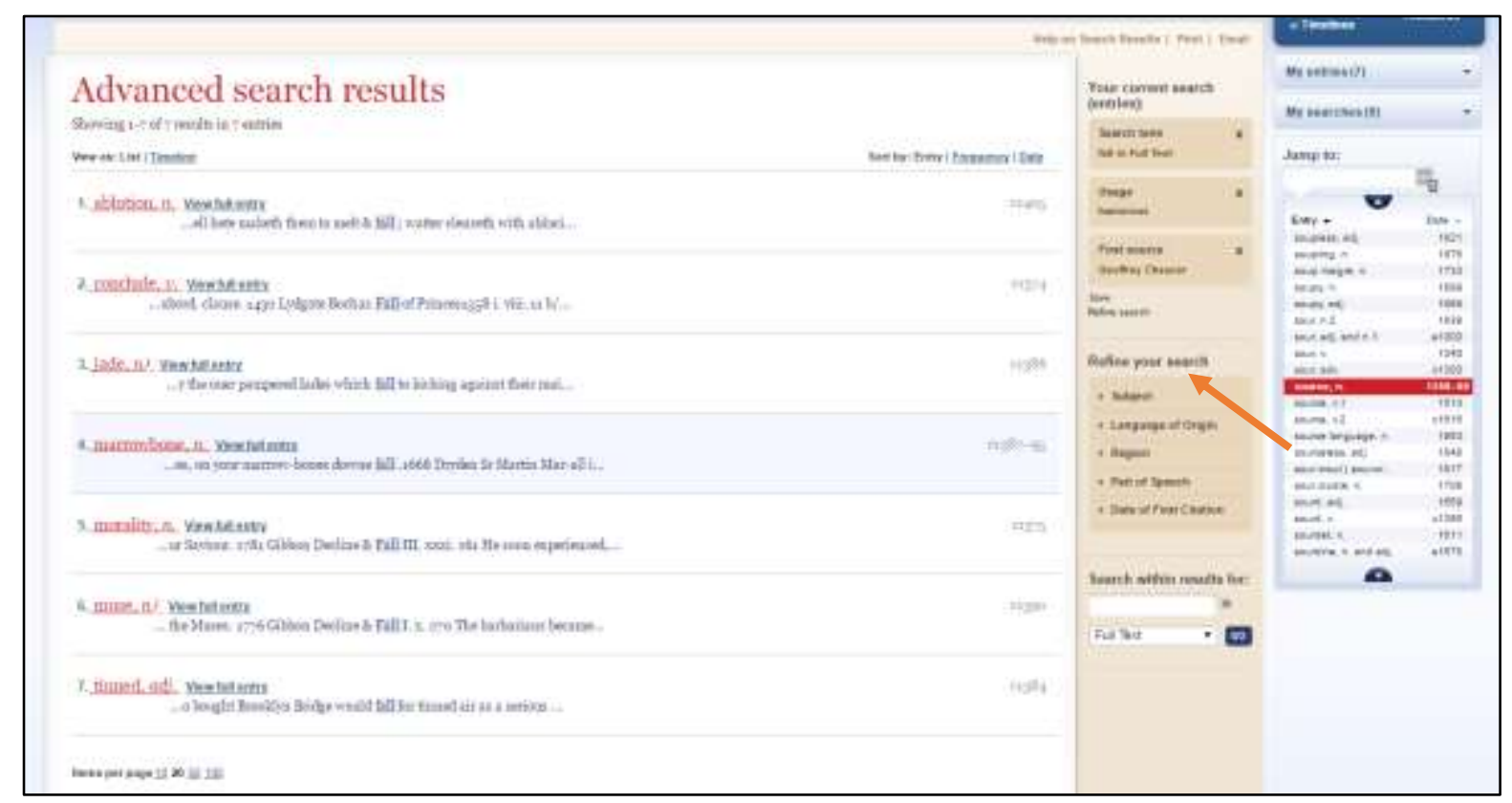

Figure 19 Refining a result set in the $O E D$

The results in the $A N W$ and Danish Dictionary of Fixed Expressions are listed according to relevance, but the $A N W$ 's results can be ordered alphabetically. The $O E D$ and Afrikaanse idiome-woordeboek list results alphabetically. In the $O E D$ the results can also be sorted by date and displayed as a timeline. The $A N W$ and $O E D$ only display a limited number of results, but the number of results can be altered by the user. The Danish Dictionary of Fixed Expressions displays a subset of the results when a large number of results are listed. There is no real page with results in the ILT. All the e-dictionaries, except the $O E D$ and Afrikaanse idiome-woordeboek, show possible matches to the user's query as the user is typing.

\subsection{Help}

The link to the 'help' for all the dictionaries, except the Danish Dictionary of Fixed Expressions, is on the home page. The link to the 'help' in the ANW is in the main menu. In the ILT there are links to help on the home page, as well as subsequent pages. The $O E D$ has a link to the help section at the top of the website as well as beneath the basic search field. The Afrikaanse idiome-woordeboek has help for each section on the home page, which can be accessed through the icon of a question mark (see Figure 20). The link to the Danish Dictionary of Fixed Expressions is on Ordbogen.com, which is host to several e-dictionaries. The help on this page is general and for all the e-dictionaries on Orbogen.com. One has to perform a search in the Danish Dictionary of Fixed Expressions to get to a page where there is help documentation for this specific dictionary. 


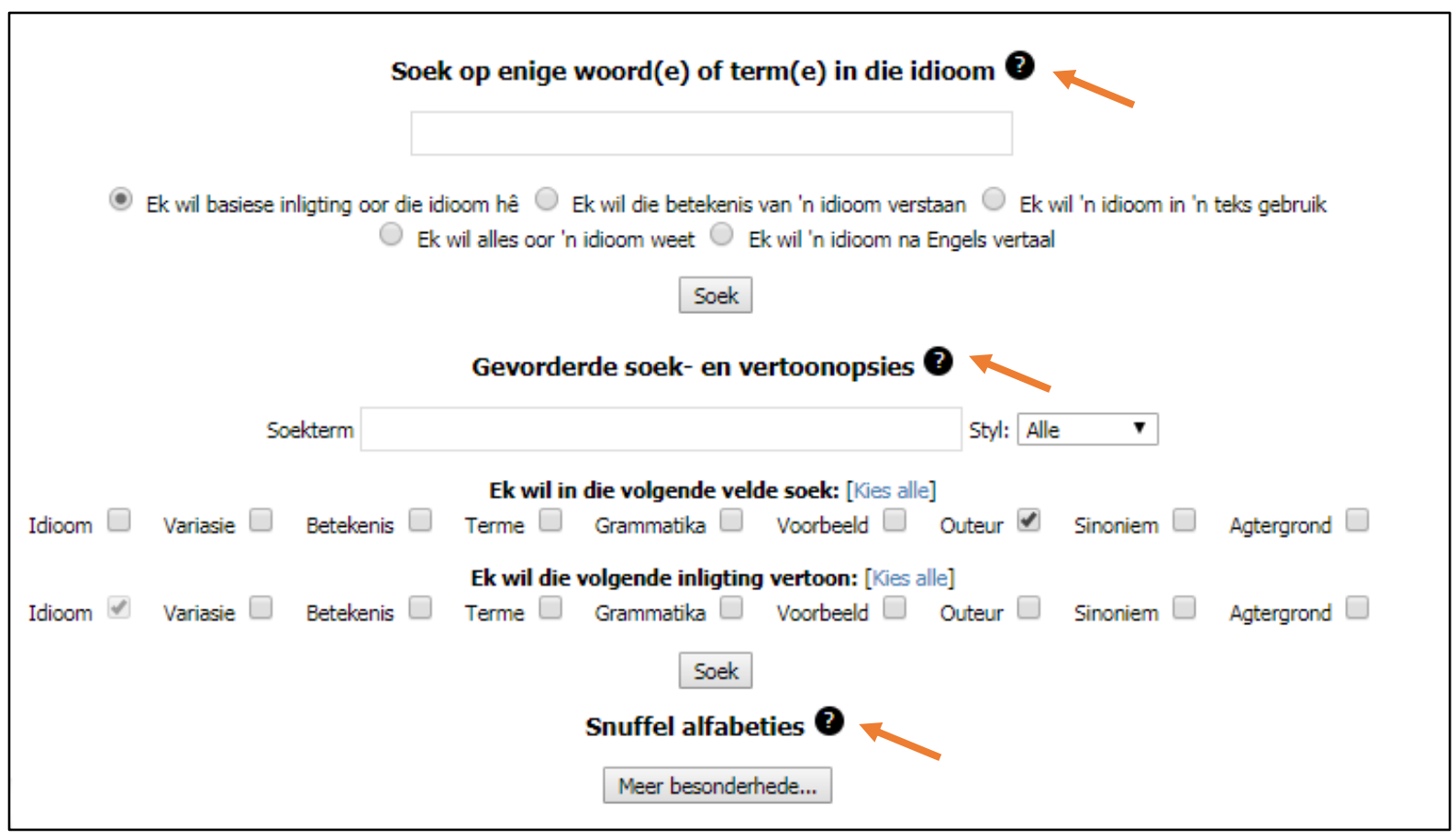

Figure 20 Help in the Afrikaanse idiome-woordeboek

The 'help' in the OED, Danish Dictionary of Fixed Expressions and the Afrikaanse idiomewoordeboek seem to be well developed and clearly documented. The $A N W$ was updated just prior to the evaluation and the help documentation still referred to the old e-dictionary at the time of evaluation. The ILT provides little help, there seem to be some errors in the documentation and some of the links are not active. However, on the home page there are helpful examples that show a user how to search in the ILT.

\subsection{Customisation}

Very few customisation options were observed in the e-dictionaries. The $O E D$ allows a user to set up a profile to save some preferences, such as number of results per page and the fields that must be showed or hidden by default on a page. Favourite entries and searches can also be saved. The Afrikaanse idiome-woordeboek allows a user to save a selection of advanced search and display fields. The selection can then be used in future searches. The search is saved with the person's email address as unique identifier. When the saved selection is retrieved, the fields in the selection are not highlighted or shown to remind the user of what they were.

\subsection{Innovative technologies}

Not many other innovative technologies were employed in the e-dictionaries, yet a few are worth mentioning. Apart from the option to search for specific information regarding a word, phrase or text, the ILT also has a writing assistant, which is an advanced tool that takes a user through a series of steps to help with writing a text. Both the OED and Danish Dictionary of Fixed Expressions connect with users through social media and a user can add a note to an article in the Danish Dictionary of Fixed Expressions.

\section{Observations and recommendations}

In many cases, it seems that although the technology to create advanced information tools exists, it is unfortunately not used. A few observations and recommendations will be made. They will be organised according to the criteria used in the previous section. 


\section{Content}

Technology makes it possible to change the level of detail of information (to show more or less information). This is not always done, or more could be done to create more refined tools.

Similarly, it is remarkable that e-dictionaries do not make more use of information from external sources. Lexicographers do not need to create everything, but can make use of the vast amount of information that is available on the Internet to enhance e-dictionaries (Bothma, 2011: 80; Heid, Prinsloo and Bothma, 2012: 273). External sources can be used on a much more detailed level than is currently the case, for example, instead of linking to a general external source on the lemma, linking to relevant sources for different senses. It can also be useful to find multimedia, such as videos or audio, that can add significant enhancement to e-dictionaries. However, it is important to remember that dictionaries still seem to be regarded as trusted tools and Heid, Prinsloo and Bothma (2012:273) suggest that, when external data are used, it should be carefully selected. The use of data from external sources could become a compromise between more information and trust. If the lexicographer handpicks all examples and illustrations, the user can know that the content is of a high quality. However, it might not be possible for the lexicographer to offer information that is as extensive as is available on the Internet. On the other hand, if a lexicographer includes links to sites that (s)he has no control over, the user is presented with more information, but the quality of the content cannot be guaranteed. For this reason, it should be clear to users when links lead to internal content and when to external content (Heid, Prinsloo \& Bothma, 2012: 285; Tarp, 2012: 264). It is therefore surprising that only the $A N W$ has a specific symbol to indicate an external source and in most of the other e-dictionaries the user has to deduce this information from the name of the link.

The technological medium makes it easy to change or edit an item, yet the date of the last update is seldom communicated to the user.

The technological medium does not have the same space restrictions as is found in print publishing and should therefore not inherit the mechanisms used to cope with such restrictions. It is strongly recommended that symbols or abbreviations are not used in e-dictionaries, or if they are used, it should be very easy to find their meaning. In the same vein, labels, headings or other such content should be clearly written, which seems to be the case.

\section{Information architecture}

It seems that the structure used in each e-dictionary is well-marked and clearly indicated to the user. It should be noted that a type of macrostructure that is presented to the user could be useful to help the user to orientate him-/herself.

\section{Navigation}

The e-dictionaries that were evaluated each seem to afford a short path to desired information. One comment here is that the Danish Dictionary of Fixed Expressions and the OED open the article directly if only one result is found. This is a small convenience, but can add to a satisfactory user experience.

\section{Search and browse}

E-dictionaries are information tools that users will typically consult to address a specific information need. It is therefore far from ideal that so few advanced search options, such as Boolean operators, truncation or the ability to search in specific fields, are used. Advanced search options can open up many exciting possibilities for the users of e-dictionaries.

The ability to browse through an information tool should strongly be considered. Not all e-dictionaries have this option. Without it, if a user is uncertain about the content of the e-dictionary or not sure how to search for something in the e-dictionary, (s)he will not be able to proceed, as searching is the only 
access route. A browsing option can at least allow him/her one other access option and perhaps to see the type of data in the e-dictionary and so to know what to search. This could be specifically relevant in specialised dictionaries.

As was seen in the evaluation, the $O E D$ is the only e-dictionary that allows a user to search within the results that have been retrieved after a search. If more advanced search options are included in an edictionary, more results may be retrieved. If a large number of results are returned, it could be difficult to find the desired result. This would make it necessary for a user to search further within the results or manipulate the results to some extent.

\section{Help}

The 'help' in most of the e-dictionaries is not implemented as well as it could be. Technology to develop proper, context-sensitive help does exist, but it is not used. This could be tested more extensively, for example, what type of help a user needs, where they look for it and in what ways can it be presented most effectively. For example, 'help' could be displayed when a user hovers with the mouse over certain items. This is a fairly obtrusive method and it should probably be possible to disable it.

\section{Customisation}

The ability to save some preferences is useful. It is recommended that the preferences or selections that are stored are clearly communicated to the user.

\section{Conclusion}

Through these evaluations, the evaluation criteria developed by Ball (2016) and Ball and Bothma (2018) are validated. They can be used to identify usability issues in e-dictionaries, as was done with the five e-dictionaries that were evaluated in this study. Ball and Bothma (2018) pointed out that these criteria can be useful for both publishers and librarians when developing or purchasing advanced information tools such as e-dictionaries. This article demonstrates how the criteria should be applied, for example, what to look for under advanced search features and how to comment on them.

Heuristic evaluations are fairly inexpensive usability tests. For publishers, heuristic evaluations can be done regularly and from the early stages throughout the development of a new product, resulting in, small changes being made often, rather than major restructuring at the end. Similarly, librarians can use this inexpensive method to evaluate e-dictionaries before purchasing tools for their patrons.

Heuristic evaluation is a useful usability evaluation method that is recommended for recognising issues in a design, as has been explained in this article. Another usability evaluation method is user testing. To do a comprehensive usability evaluation, it is recommended that user testing with real users is done when e-dictionaries are evaluated to supplement the findings from the experts in heuristic evaluation. The criteria followed in this article can also be used to create tasks for users for evaluating a product. An example of user testing based on these criteria is explained in Ball and Bothma (2017a \& b).

As lexicographers continue to dream of the ideal dictionary and create dictionaries based on different theories, such as the function theory, and different technologies, such as multimedia, advanced search features, filtering or linking to external sources, it is highly recommended that they keep the criteria for e-dictionaries in mind and do rigorous usability evaluation. The usability evaluation in Ball and Bothma (2017a) has demonstrated that developers of e-dictionaries do not necessarily share the same views as the users of such products. Therefore, as developers are experimenting with new forms of dictionaries, usability evaluation becomes increasingly important.

Usability evaluations can be used to improve e-dictionaries and create tools that can be more useful in addressing real information needs of users. Publishers and librarians can use these criteria to perform 
usability evaluation of advanced e-dictionaries to ensure that they produce or subscribe to information tools that can be used effectively, efficiently and with great satisfaction.

\section{E-dictionaries used in this study}

Afrikaanse idiome-woordeboek (2016) - http://www.aivuw.co.za

Algemeen Nederlands Woordenboek (ANW) (2016) - http://anw.inl.nl/search

Interactive Language Toolbox (ILT) (2016) - https://ilt.kuleuven.be/inlato/

Ordbogen over faste vendinger (Danish Dictionary of Fixed Expressions) (2016) -

http://www.ordbogen.com/

Oxford English Dictionary (OED) (2016) - http://www.oed.com/

\section{References}

ANW. (2015), "Over het ANW”, available at: http://anw.inl.nl/about (accessed 21 July 2015).

Ball, L.H. (2016), "An evaluative study to determine to what extent technology can be used in edictionaries to provide relevant information on demand", Master's thesis, University of Pretoria.

Ball, L.H. \& Bothma, T.J.D. (2017a), "A usability evaluation of the prototype Afrikaanse idiomewoordeboek", Lexikos (in press).

Ball, L.H. \& Bothma, T.J.D. (2017b), "The importance of usability evaluation when developing digital tools for a library - a case study", Proceedings of Bobcatsss 2017, 25-27 January 2017, Tampere, Finland (in press).

Ball, L.H. \& Bothma, T.J.D. (2018), "Establishing evaluation criteria for e-dictionaries", Library HiTech, Vol. 36, No. 1, pp. 152-166.

Barnum, C.M. (2010), Usability Testing Essentials, Morgan Kaufmann, Burlington.

Bergenholtz, H. (2012), "Ordbogen over faste vendinger - Center for Leksikografi” available at http://www.ordbogen.com/products/center-for-leksikografi/ordbogen-over-fastevendinger.php?product_id=10\#Introduktion (accessed 26 February 2016).

Bergenholtz, H., Bothma, T. \& Gouws, R. (2011), "A model for integrated dictionaries of fixed expressions", Kosem, I. \& Kosem, K. (Eds.), Electronic lexicography in the 21st century: New applications for new users: Proceedings of eLex 2011, Bled, Slovenia, 10-12 November 2011, Trojina, Institute for Applied Slovene Studies, Ljubljana, pp. 34-42.

Bothma, T.J.D. (2011), "Filtering and Adapting Data and Information in an Online Environment in Response to User Needs", in Bergenholtz, H. \& Fuertes-Olivera, P.A. (Eds.), e-Lexicography: The Internet, Digital Initiatives and Lexicography, Continuum International Publishing Group, London, pp. 71-102.

Bothma, T.J.D. \& Tarp, S. (2012), "Lexicography and the Relevance Criterion”, Lexikos, Vol, 22, pp. 86-1008.

De Schryver, G. (2003), "Lexicographers' Dreams in the Electronic-Dictionary Age", International Journal of Lexicography, Vol. 16, No. 2, pp. 143-199.

Fernandez, A., Insfran, E. \& Abrahão, S. (2011), "Usability evaluation methods for the web: A systematic mapping study", Information and Software Technology, Vol. 52, No. 8, pp. 789-817. 
Gouws, R.H. (2014), “Makrostruktuuraanpassings vanaf gedrukte na e-woordeboeke”, Tydskrif vir Geesteswetenskappe, Vol. 54, No. 3, pp. 481-504.

Heid, U. (2011), "Electronic Dictionaries as Tools: Toward An Assessment of Usability", in Bergenholtz, H. \& Fuertes-Olivera, P.A. (Eds.), e-Lexicography: The Internet, Digital Initiatives and Lexicography, Continuum International Publishing Group, London, pp. 287-304.

Heid, U., Prinsloo, D.J. \& Bothma,T.J.D. (2012), "Dictionary and corpus data in a common portal: state of the art and requirements for the future", Lexicographica, Vol. 28, No. 1, pp. 269-291.

ISO 9241-11. (1998), "ISO 9241-11:1998 Ergonomic requirements for office work with visual display terminals (VDTs) - Part 11: Guidance on usability", available at http://www.iso.org/iso/catalogue_detail.htm?csnumber=16883 (accessed 2 August 2016).

Lew, R. (2012), "How can we make electronic dictionaries more effective?" in Granger, S. \& Paquot, M. (Eds.), Electronic Lexicography, Oxford University Press, Oxford, pp. 343-361.

Nesi, H. (2000), The use and abuse of EFL dictionaries: how learners of English as a foreign language read and interpret dictionary entries, Niemeyer, Tübingen.

Nielsen, J. (1993), Usability Engineering, Academic Press, Cambridge.

OED. (2013a), “About the OED”, available at: http://public.oed.com/about/ (accessed 18 September 2015).

OED. (2013b), "The OED and Oxford Dictionaries", available at: http://public.oed.com/about/theoed-and-oxford-dictionaries/ (accessed 18 September 2015).

OED. (2013c), "History of the OED", available at: http://public.oed.com/history-of-the-oed/ (accessed 18 September 2015).

Preece, J., Rogers, Y. \& Sharp, H. (2011), Interaction Design. Beyond human-computer interaction, 3rd ed., John Wiley \& Sons, Chichester.

Rubin, J., Chisnell, D. \& Spool, J. (2008), Handbook of Usability Testing: How to Plan, Design, and Conduct Effective Tests, John Wiley \& Sons, Indianapolis.

Shneiderman, B. \& Plaisant, C. (2010), Designing the user interface. Strategies of effective humancomputer interaction, 5th ed., Pearson Education, Boston.

Tarp, S. (2009), "Reflections on lexicographical user research”, Lexikos, Vol. 19, pp. 275-296.

Tarp, S. (2011), "Lexicographical and Other E-Tools for Consultation Purposes: Towards the Individualization of Needs Satisfaction", in Bergenholtz, H. \& Fuertes-Olivera, P.A. (Eds.), eLexicography: The Internet, Digital Initiatives and Lexicography, Continuum International Publishing Group, London, pp. 54-70.

Tarp, S. (2012), “Online dictionaries: today and tomorrow”, Lexicographica, Vol. 28, No. 1, pp. 253268.

Tempelaars, R. (2014), "Algemeen Nederlands Woordenboek (ANW), a dictionary of contemporary Dutch", available at: http://www.elexicography.eu/wp-content/uploads/2014/11/Bled-ANW-2014.pdf (accessed 21 July 2015).

Tiberius, C., Niestadt, J. \& Schoonheim, T. (2014), “The INL dictionary writing system”, in Kosem, I. \& Rundell, M. (Eds.) Slovenščina 2.0: Lexicography, Vol. 2, No. 2, pp. 72-93. 
Tullis, T. \& Albert, W. (2008), Measuring the User Experience: Collecting, Analyzing, and Presenting Usability Metrics. Morgan Kaufmann, Burlington.

Verlinde, S. \& Peeters, G. (2012), "Data access revisited: The Interactive Language Toolbox", in Granger, S. \& Paquot, M. (Eds.) Electronic Lexicography, Oxford University Press, Oxford. 


\section{Appendix A}

This set of criteria is based on Ball and Bothma (2018).

\begin{tabular}{|c|c|}
\hline \multicolumn{2}{|l|}{ Content } \\
\hline Level of detail and complexity & $\begin{array}{l}\text { To what extent does the e-dictionary make use of } \\
\text { external sources to provide extra information? }\end{array}$ \\
\hline Currency & $\begin{array}{l}\text { - Can a user easily establish when a page was last } \\
\text { updated? } \\
\text { - Are the external links on the page current and } \\
\text { active? }\end{array}$ \\
\hline Credibility & $\begin{array}{l}\text { - Can the authorship of the dictionary be } \\
\text { established? } \\
\text { Are the contact details of the publisher or editors } \\
\text { available should a user have questions or want to } \\
\text { provide feedback? }\end{array}$ \\
\hline Writing and editorial style & $\begin{array}{l}\text { - Are the labels (for synonyms, antonyms, etc.) } \\
\text { clear and not abbreviated? } \\
\text { - Are the headings and page titles clear? }\end{array}$ \\
\hline Multimedia usage & $\begin{array}{l}\text { - What multimedia is used and is it used } \\
\text { effectively? }\end{array}$ \\
\hline \multicolumn{2}{|l|}{ Information architecture } \\
\hline Organisational structure & - Are the structure and/or functions clear? \\
\hline Organisation of content on a page level & $\begin{array}{l}\text { - Are items on a page marked clearly? (Is it easy to } \\
\text { scan a page?) } \\
\text { - Are the items on a page ordered logically? } \\
\text { - Can the information to be shown on a page be } \\
\text { specified? }\end{array}$ \\
\hline \multicolumn{2}{|l|}{ Navigation } \\
\hline Ease of navigation & $\begin{array}{l}\text { - Are the navigation options clear? } \\
\text { - How long is the path to relevant information? }\end{array}$ \\
\hline User orientation & $\begin{array}{l}\text { Is feedback given to indicate the position in the e- } \\
\text { dictionary? }\end{array}$ \\
\hline Links & $\begin{array}{l}\text { - Is the difference between internal and external } \\
\text { links clearly indicated? } \\
\text { - Is it clear what information is behind a link? } \\
\text { Does the dictionary provide the option for users } \\
\text { to click on an item to go to that article instead of } \\
\text { searching for that item? }\end{array}$ \\
\hline \multicolumn{2}{|l|}{ Access } \\
\hline Basic search & $\begin{array}{l}\text { - Is the search field easy to identify? } \\
\text { - Is the search field available from all pages? }\end{array}$ \\
\hline Advanced search & - What advanced search features are provided? \\
\hline
\end{tabular}




\begin{tabular}{|c|c|}
\hline Browsing & - What browsing options are available? \\
\hline Filtering & - How is filtering used in the e-dictionary? \\
\hline Viewing and manipulation of results & $\begin{array}{l}\text { - How are search results displayed? } \\
\text { - To what extent can search results be } \\
\text { manipulated? }\end{array}$ \\
\hline \multicolumn{2}{|l|}{ Help } \\
\hline Help and documentation available & $\begin{array}{l}\text { - Is the help easily accessible? } \\
\text { - How clear and thorough is the help? }\end{array}$ \\
\hline \multicolumn{2}{|l|}{ Customisation } \\
\hline $\begin{array}{l}\text { Customisation options in the e- } \\
\text { dictionary }\end{array}$ & $\begin{array}{l}\text { - To what extent does the e-dictionary adapt to the } \\
\text { needs and characteristics of the user? } \\
\text { - Can user profiles be created and if so, how } \\
\text { effectively is this done? } \\
\text { - To what extent is data marked up (annotated) to } \\
\text { adapt according to the user profile? }\end{array}$ \\
\hline \multicolumn{2}{|l|}{ Innovative technologies } \\
\hline $\begin{array}{l}\text { Innovative technologies used to } \\
\text { manage information in e-dictionaries }\end{array}$ & $\begin{array}{l}\text { To what extent are innovative technologies used } \\
\text { to manage information in the e-dictionary, for } \\
\text { example, recommendations, annotations, decision } \\
\text { trees? }\end{array}$ \\
\hline
\end{tabular}

